\title{
BLACKMAIL AS PRIVATE JUSTICE
}

\author{
JENNIFER GERARDA BROWN†
}

You must not distort justice; you must not show partiality; and you must not accept bribes, for a bribe blinds the eyes of the wise and subverts the cause of those who are in the right. Justice, and only justice, you shall pursue. 1

[A]ny person ... may freely come into, and attend the said courts, and hear and be present, at all or any such tryals as shall be there had or passed, that justice may not be done in a cormer nor in any covert manner. ${ }^{2}$

\section{INTRODUCTION}

If people could legally blackmail criminals by threatening to reveal their criminal activity unless paid a fee, would we have less crime? This Article suggests that we might, and it explores the implications of such a response. Along the way, the Article seeks to identify the real "victims" of blackmail (if any), examine the legitimacy of claims that blackmail should always be illegal, and assess the rationales for prohibition.

This is not uncharted territory. Scholars of various disciplines have worked over the years to explain the illegality of blackmail. This Symposium attests to the popularity of blackmail's peculiar puzzles. This Article, however, explores only a limited part of the blackmail landscape; ${ }^{3}$ the exclusive focus is blackmail based on

† Assistant Professor of Law, Emory University. I am grateful to Barry Adler, Jennifer Arlen, Ian Ayres, William Carney, Morgan Cloud, Andrew Kull, Marc Miller, Timothy Terrell, and Deborah Young for helpful comments and conversations.

${ }^{1}$ Deuteronomy 16:19-20 (Oxford ann.)

2 The 1677 Concessions and Agreements of West New Jersey, reprinted in SOURCES OF OUR LIBERTIES 188 (Richard L. Perry ed., 1959), (cited in Richmond Newspapers, Inc. v. Virginia, 448 U.S. 555, 567 (1980)).

${ }^{3}$ Others have set forth a more complete taxonomy of blackmail and have explained the illegality of each category of blackmail separately. See, e.g., JOEL FEINBERG, HARMLESS WRONGDOING 240-76 (1988) (discussing blackmail and debating whether the state can rightfully criminalize, on the ground of its moral wrongfulness, conduct that harms no one); Richard A. Posner, Blackmail, Privacy, and Freedom of Contract, 141 U. PA. L. REV. 1817, 1820-36 (1993) (setting forth and analyzing separately seven types of information that a blackmailer might threaten to reveal). See generally James Lindgren, Unraveling the Paradox of Blackmail, 84 Colum. L. Rev. 670, 670-73 (1984) (criticizing eight theories of blackmail and 
incriminating information ("incriminating blackmail"). Some argue that this sort of blackmail is not "paradoxical" because the blackmailer offers or threatens to violate a legal or civic duty owed to another. ${ }^{4}$ I argue, in contrast, that incriminating blackmail is potentially paradoxical because it might confer social benefits not produced by other kinds of blackmail. If blackmailers were permitted to collect a fee in exchange for silence about crimes, they could impose costs on criminals that might increase the deterrence achieved solely by public law enforcement. Granted, blackmail might also benefit criminals by allowing them to postpone detection by public officials. But this potential benefit to some criminals would not necessarily exceed the additional costs imposed by blackmail.

Incriminating blackmail could impose additional costs on criminals in various ways. First, if incriminating blackmail were legal, some people might gain an incentive to acquire incriminating information deliberately and use the information to blackmail criminals. Second, in an imperfect world where many people know about crimes but fail to report the wrongdoers to police, much incriminating information is never put to use. If incriminating blackmail were legal, some people with casually acquired information $^{5}$ (who do not report under the present system) might have an incentive to put that information to use by blackmailing criminals. Third, if criminals refused to pay in such a system, blackmailers who expect to be repeat players might have an increased incentive to report crimes to police, if only to make blackmail threats credible in the future. Thus, even if blackmail caused the probability of public detection to fall in some cases, this loss could be more than

arguing that blackmail should be criminalized because it involves misappropriating a third party's leverage for the blackmailer's own advantage over the victim).

${ }^{4}$ See FEINBERG, supra note 3, at 240-46 (arguing that the illegality of incriminating blackmail presents a "paradox lost" because incriminating blackmail requires the blackmailer to violate a duty to report crime); Douglas Ginsburg \& Paul Shechtman, Blackmail: An Economic Analysis of the Law, 141 U. PA. L. REV. 1849, 1858 (1993) (asserting that the illegality of incriminating blackmail is explained by the fact that the blackmailer "default[s] on a duty" to the state to report crime; oddly accepting the duty to report crime as given despite their claim to give blackmail a fresh analysis from the perspective of a "rational economic planner.").

${ }^{5}$ People gain "casually acquired information" fortuitously-without expending time or other resources on investigation. "Deliberately acquired information," as the name suggests, requires some effort to uncover. See Anthony T. Kronman, Mistake, Disclosure, Information, and the Law of Contracts, 7 J. LEGAL STUD. 1, 13-14 (1978). 
compensated by increased use of both casually and deliberately acquired information by private blackmailers. ${ }^{6}$ We are faced at the very least with an interesting empirical question, for if incriminating blackmail could raise the potential costs of crime and thus improve general deterrence, incriminating blackmail could be socially beneficial in ways that other forms of blackmail are not.

Thus, this Article sets out the best case for blackmail before concluding that it should be illegal. To analyze the wrongful element of blackmail, we must define more fully the interests of the blackmailer and the public. Their interests are clearly different, but we must be more precise about the point at which their interests diverge. As a vehicle for such discussion, this Article considers what might happen if a legislature were to tailor the law of blackmail to maximize and capture the potential social benefits of the activity while also minimizing its social costs. This tailoring could be achieved through an affirmative defense protecting blackmailers who threaten to reveal incriminating (not just negative or embarrassing) information. ${ }^{7}$

Even in the "best case" scenario, this arguably productive form of blackmail remains unappealing. The leading moral and economic theories of blackmail do not sufficiently explain why such a scheme is undesirable, but their failure does not signal that incriminating blackmail should be allowed in this way. Even if one could demonstrate with certainty that blackmail could efficiently deter crime, most people would probably resist decriminalization. The intuitive resistance to decriminalization of blackmail may reveal the limits of the deterrence theory of criminal justice. Although economists have cited deterrence as the primary and perhaps sole purpose of criminal law, economic analysis is incomplete if it does not account for the other ways in which public enforcement of the criminal law is socially beneficial.

Incriminating blackmail may remain illegal despite its contribution to deterrence because blackmail might achieve deterrence at

${ }^{6}$ In any case, the point is not that blackmail is devoid of benefit to the criminal, but rather, that the literature about blackmail has given short shrift to the ways blackmail might generally deter crime by imposing additional potential costs on criminals-costs that might outweigh its benefits to them.

${ }^{7}$ Cf. James Lindgren, More Blackmail Ink: A Critique of Blackmail, Inc., Epstein's Theory of Blackmail, 16 CONN. L. REV. 909, 921-22 (1984) (addressing the concern that blackmail is illegal because it can lead blackmailees to steal in order to make payments, Lindgren facetiously suggests a limited affirmative defense that would excuse any blackmail that is "too moderate to induce theft"). 
the expense of other goals of the criminal justice system. Judges, legislators, and scholars have articulated these additional goals in various ways, frequently citing retribution, incapacitation, and rehabilitation. Often, these purposes are associated with punishment-the criminal's fate in the wake of conviction. Additional goals of criminal justice-education of the public and declaration of societal norms-are reflected at all stages of the process, from legislation to incarceration. These purposes are achieved only to the extent that criminal justice activity has an audience-a community to whom and by whom the norms are declared. To achieve this goal, criminal justice cannot be private justice. The public declaration of rights and responsibilities through interpretation and application of the criminal laws remains an important political function of the government, one that renders substantial, if intangible, social benefits. Although deterrence is one goal of criminal justice, it may be less important than the declarative purpose of the criminal law. The illegality of blackmail, a form of private justice, reflects this desire to keep all law enforcement activity in the light of public scrutiny and involvement.

\section{THE BEST GASE FOR INCRIMINATING BLACKMAIL}

A state could decriminalize blackmail when it involves threats to disclose the blackmailee's criminal activity ${ }^{8}$ that has not yet been detected or punished. Blackmail would generally remain illegal and the state would continue to prosecute blackmail cases, but the law would recognize an affirmative defense for cases involving blackmail of criminals. 9 In a criminal prosecution for blackmail, the defen-

${ }^{8}$ Threats to disclose criminal conduct are significantly different from threats to reveal noncriminal, potentially embarrassing activity or conditions. When blackmailers threaten people involved in noncriminal activity, they deter activities that are not prohibited by criminal law. The failure to criminalize signals a view that when people violate certain norms, they have not damaged the social fabric sufficiently that the community is aggrieved and has a public right of action against the violators. See William M. Landes \& Richard A. Posner, The Private Enforcement of Law, 4 J. LEGAL STUD. 1, $42-43$ (1975) (stating that the illegality of blackmail based on potentially embarrassing but not incriminating information reflects "[ $t]$ he social decision not to regulate a particular activity" and "a judgment that the expenditure of resources on trying to discover and punish it would be socially wasted").

"In a criminal case, the term "affirmative defense" traditionally describes the allocation of a burden, either of production or persuasion, or both, to the defendant. See 9 JOHN H. WIGMORE, EvideNCE \$§ 2501, 2512, 2514 (James H. Chadbourn ed., 1981). The nature of that burden is somewhat flexible: The 
dant could present an affirmative defense that the blackmailee was engaged in criminal activity that was not yet punished, and the blackmailer threatened to report the crime if the criminal didn't pay up. The defendant would bear the burden of determining (and later of proving by a preponderance of the evidence) ${ }^{10}$ that the blackmailee had indeed committed a crime covered by the affirmative defense. ${ }^{11}$

The legislature could reasonably determine for a variety of reasons that blackmail would work efficiently as a private enforcement mechanism only with respect to certain crimes. It would have to determine the specific crimes or categories of crimes subject to blackmail, and include the list when recognizing the affirmative defense. Crimes to be included would be determined by the conditions and character of the jurisdiction and its specific law enforcement priorities. ${ }^{12}$ The key to the success of the affirmative defense would be a legislative judgment that the class of criminals

defendant may simply have the burden of production of evidence regarding a matter in defense; if the defendant satisfies that burden, the prosecution must bear a burden of production and the burden of persuasion. In other instances, the defendant bears both the burden of production and the burden of persuasion. See MCCORMICK ON EVIDENCE 987-88 (Edward W. Cleary ed., 3d ed. 1984).

${ }^{10}$ See MCCORMICK ON EVIDENCE, supra note 9, at 988 ("Usually, the measure of persuasion imposed on the defendant with regard to an affirmative defense is a preponderance of the evidence."); see also Patterson v. New York, 432 U.S. 197, 206 (1977) ("[T] The State may refuse to sustain the affirmative defense of insanity unless demonstrated by a preponderance of the evidence."); State v. McCauley, 43 S.E.2d 454, 461 (W. Va. 1947) ("[T]he defendant's insanity must be proven by him ... by a preponderance of the evidence.") (footnote omitted).

11 If blackmailers are to perform the function of private law enforcers, they should be certain that they are imposing fines only where the law has actually been broken. Moreover, forcing the blackmailer to bear the burden of persuasion on the affirmative defense will protect the privacy of blackmailees more effectively than a scheme in which the prosecutor must prove the noncriminality of the blackmailee's conduct as an element of the crime. If the prosecutor has to prove the noncriminal character of the blackmailee's conduct each time a blackmailer is prosecuted, then the blackmailee's affairs are implicated in every case. If, on the other hand, the blackmailer has available an affirmative defense based on the criminal conduct of the blackmailee, the blackmailee's privacy will be disturbed less frequently, and only in cases in which the defendant can produce some evidence of the crime.

12 For example, the legislature might determine that in some neighborhoods or communities, people readily and frequently tip off the police about certain crimes, while in other communities, people try to minimize interaction with law enforcement officials and might require additional, economic incentives to use incriminating information they might have. Thus, empirical data about the culture and reporting behaviors of an identified community could help guide a legislature in defining the range of crimes covered by the statute. 
subject to blackmail would be engaged in activity the legislature wished to deter, and that these criminals might be deterred by increasing their potential costs through blackmail.

For example, if drug traffickers within the jurisdiction tend as a group to be extremely violent, the legislature might not want to give people an incentive to blackmail this group of criminals. The legislature might fear the social costs of increased violence in response to blackmail proposals. In addition, the legislature might determine that increasing the costs of drug dealing is unlikely to deter people from entering the industry. The increased costs imposed might not outweigh the economic rents collected by drug dealers, who generally face inelastic demand curves and have relatively low opportunity costs. ${ }^{13}$

On the other hand, people engaged in embezzlement, bank fraud, or other white collar crimes might be unlikely to react violently to a blackmail proposal, so that allowing blackmail would not impose as many social costs in the form of increased violence. Certain kinds of crime might be detected more easily and more cheaply by watchful private citizens than by public officials. Embezzlement, for example, could be detected by a careful client, supervisor, or co-worker despite the embezzler's attempts to conceal the crime from public authorities. White collar criminals also might be more likely than most criminals to calculate the potential costs of their contemplated crime ex ante, making the possibility of blackmail an effective deterrent. Moreover, because many business and banking industries are subject to government regulation, people likely to engage in criminal activity could be easily informed that they could be subject to blackmail if they were to violate particular laws. Allowing blackmail of these criminals, then, might increase the criminals' perceived potential costs without imposing heavy social costs.

The wisdom of this affirmative defense rests upon an assumption that blackmail of criminals might be a productive activity, and it is to this assertion that we now turn.

13 See A. Morgan Cloud, III, Cocaine, Demand, and Addiction: A Study of the Possible Convergence of Rational Theory and National Policy, 42 VAND. L. REv. 725, 757-76 (1989) (presenting an economic analysis of the market for cocaine, including elasticity of demand and deterrence effects from criminal penalties). 


\section{The DeterRence Value of Blackmail}

\section{A. An Economic Model of Deterrence}

Economists argue that optimal penalties can deter criminal activity. ${ }^{14}$ They assert that an important purpose of criminal sanctions is to make the expected cost of criminal activity exceed its expected benefit to the criminal. ${ }^{15}$ Some economists argue that

14 See ROBERT COOTER \& ThOMAS ULEN, LAW AND Economics 515-32 (1988) (concluding that increasing the probability or severity of penalty will reduce crime); A. MITCHELl POLINSKy, AN INTRODUCTION TO LAW AND ECONOMICs 75-86 (2d ed. 1989) (discussing the relationship between penalty, enforcement, and risk questions); RICHARD POSNER, ECONOMIC ANALYSIS OF LAW 223-31 (4th ed. 1992) [hereinafter ECONOMIC ANALYSIS OF LAW] (discussing optimal criminal sanctions). But see Posner supra note 3, at 1822 ("Punishment is rarely optimal in any strong sense."). Certainly, the proposition that crime can be optimally deterred through heavy penalties is not uncontroversial. The causes of crime are many, and increasing penalties will probably not deter crimes that stem from some of these causes. Moreover, deterrence does not appear to be the only or even the primary purpose of the criminal law. For example, the United States Federal Sentencing Guidelines encourage judges to consider the purposes of punishment when meting out sentences, and deterrence is only one of several purposes mentioned:

The court, in determining the particular sentence to be imposed, shall consider-

...

(2) The need for the sentence imposed-

(A) to reflect the seriousness of the offense, to promote respect for the law, and to provide just punishment for the offense;

(B) to afford adequate deterrence to criminal conduct;

(C) to protect the public from further crimes of the defendant; and

(D) to provide the defendant with needed educational or vocational training, medical care, or other correctional treatment in the most effective manner ....

Federal Sentencing Guidelines, 18 U.S.C. $\$ 3553($ a) (1988).

${ }^{15}$ See ECONOMIC ANALYSIS OF LAW, supra note 14, at 224 ("[T]he criminal sanction ought to be so contrived that the criminal is made worse off by committing the act."). For example, if a person who is risk-neutral is considering stealing an object worth $\$ 1000$, one might think that the prospect of making restitution to the victim (giving the object back to the victim or paying the victim $\$ 1000$ ) plus perhaps an additional fine of $\$ 1$ would be enough to deter the person from stealing, because the expected costs $(\$ 1001)$ are greater than the benefits from stealing. But if the probability of detection and conviction is less than one, as it almost certainly is with burglaries, the expected cost of the crime to the would-be burglar is less than $\$ 1000$. If, for example, there is only a one in five chance that the burglar will be caught and punished, the expected cost of the crime is only $\$ 200.20$ or $(\$ 1001) *(.2)$. In order to raise the expected costs of the crime above the expected benefits, the government must increase the penalty, the probability of conviction, or both. If the government is unwilling to increase the probability 
a rational system of law enforcement will try to achieve the optimal level of deterrence with the minimum expenditure of resources on law enforcement. ${ }^{16}$ When fewer resources are spent on enforcement, the probability of detection and conviction decreases and the state must raise criminal penalties in order to maintain deterrence. Some empirical work, however, suggests that "certainty of punishment rather than severity of punishment is the key to deterring criminal behavior. ${ }^{n 17}$ This may be because people calculate the expected costs of events less accurately as the probability of those events decreases. ${ }^{18}$ People might calculate the costs of crime inaccurately if the probability of detection is very small and the government relies on a very heavy penalty to maintain high costs of criminal activity. If people underestimate the costs of the criminal activity, they could be insufficiently deterred. ${ }^{19}$

of detection and conviction by spending more resources on law enforcement, it must increase the burglar's penalty to $\$ 5005$ in order to keep the expected cost of crime above the expected benefits $(\$ 5005) *(.2)=\$ 1001$, which is greater than $\$ 1000$. Although this economic model may seem to overestimate the extent to which potential criminals consider the costs of their activity, empirical studies have shown that criminals respond to changes in the probability of apprehension, severity of punishment, and other costs, such as opportunity costs. See CoOTER \&c ULEN, supra note 14, at 524-28; DETERRENCE AND INCAPACITATION: ESTIMATING THE EFFECTS OF CRIMINAL SANCTIONS ON CRIME RATES (Alfred Blumstein et al. eds., 1978); ECONOMIC ANALYSIS OF LAW, supra note 14, at 224 n.1; Alfred Blumstein \& Daniel Nagin, The Deterrent Effect of Legal Sanctions on Draft Evasion, 29 STAN. L. REv. 241 (1977); Isaac Ehrlich, Participation in Illegitimate Activities: $A$ Theoretical and Empirical Investigation, 81 J. POL. ECON. 559-61 (1973).

${ }^{16}$ See, e.g., Gary S. Becker, Crime and Punishment: An Economic Approach, $76 \mathrm{~J}$. POL. ECON. 169 (1968) (setting up mathematic equations to analyze the variable costs of reducing crime to an optimal level).

17 Blumstein \& Nagin, supra note 15, at 243 \& n.8 (1977); see also Johannes Andenaes, The General Preventative Effects of Punishment, 114 U. PA. L. REv. 949, 962 (1966) (discussing the great rise in burglary in Denmark when the Germans began arresting Danish police in 1944).

${ }^{18}$ See Daniel Kahneman \& Amos Tversky, Decision Research, Prospect THEORY: AN ANALYSIS OF DECISION MAKING UNDER RISK 3-2 (1977) (Technical Report PTR-1042-77-4) (discussing overweighting of probabilities and attitudes towards uncertainty that may lead to increases in decision-makers' risk aversion where loss may be substantial); see also RICHARD NISBETT \& LEE ROSS, HUMAN INFERENCE: STRATEGIES AND SHORTCOMINGS OF SOCIAL JUDGMENT 165 (1980) (stating that people underestimate the risk of uncertain negative consequences); Daniel Kahneman \& Amos Tversky, Judgment Under Uncertainty: Heuristics and Biases, 185 SCIENCE 1124, 1126 (1974) (describing how available information is used, so even if probability is low, heavily publicized arrests would deter crime).

19 See John J. Donahue III \& Ian Ayres, Posner's Symphony No. 3: Thinking About the Unthinkable, 39 STAN. L. REV. 791, 800 n.43 (1987) (reviewing RICHARD A. POSNER, ECONOMIC ANALYSIS OF LAW (3d ed. 1986)) (stating that a law and economics model of deterrence that preserves society's resources by heavily 
Thus, if government spends few resources on law enforcement pursuant to a theory that optimal deterrence will be achieved through very high fines, people may be insufficiently deterred because they may underestimate the probability of the fines being imposed. Increasing enforcement activity might bring the probability of detection to a high enough level that people would once again accurately assess the costs of criminal activity. ${ }^{20}$ Other policy considerations also support increasing the probability of detection and conviction. Noncriminals as well as criminals may generally feel a greater respect for the law when they see it enforced more frequently, regardless of the severity of the punishment. ${ }^{21}$ Moreover, a person whose criminal activity is detected and punished when it remains at a less serious level may be specifically deterred from committing more serious crimes that impose greater social costs. Increasing the probability of detecting less serious crimes may prevent more serious criminal activity by the same people in the future.

\section{B. Blackmail as a Mechanism of Criminal Law Enforcement}

Anyone who believes in optimal penalties capable of deterring all inefficient crimes would probably reject the notion that allowing blackmail might improve deterrence. Once we recognize that a government might feel constrained in setting fines or penalties, however, ${ }^{22}$ we start to see a role for incriminating blackmail.

punishing fewer criminals conflicts with social science, because social scientists believe "decisionmakers appear to underestimate systematically the risk of uncertain negative consequences" and would be deterred more effectively by an increased likelihood of punishment).

${ }^{20}$ See Thorsten Sellin, The Law and Some Aspects of Criminal Conduct, in CoNFERENCE ON AIMS AND MeTHODS OF Legal Research 113, 119-20 (Greenwood Press 1969) (1957) (discussing sharp drops in crime rates in one New York precinct when the city tripled the number of police officers assigned to the area); Kenneth I. Wolpin, An Economic Analysis of Crime and Punishment in England and Wales, 1894-1967, $86 \mathrm{~J}$. POL. ECON. 815, 823-33 (1978) (analyzing how changes in the probability of being punished affect crime rates).

21 See Michel foucault, Discipline and Punish: The BIRTH of the Prison 96 (Alan Sheridan trans., 1977) (1975) ("Nothing so weakens the machinery of the law than the hope of going unpunished; how could one establish in the minds of the public a strict link between the offense and a penalty if it were affected by a certain coefficient of improbability?"); see also Donahue \& Ayres, supra note 19, at 800 n.43 (contrasting Posner's view of deterrence with that of Cesare Beccaria). For further discussion of the benefits from public declaration of criminal conduct and its consequences, see infra part I.B.

22 The state might keep official fines for a given offense below the optimal 
Allowing incriminating blackmail could effectively increase levels of law enforcement activity and raise the potential criminal's expected costs. ${ }^{23}$ Through blackmail, people could benefit from information about another's criminal activity, and thus gain an incentive to investigate crimes. Increased investigation could raise the likelihood that crimes would be detected and costs imposed on the criminals. Even when based on casually acquired information, incriminating blackmail could increase deterrence.

Four hypothetical jurisdictions with different rules demonstrate the possible deterrence value of allowing incriminating blackmail:

JURISDICTION $A$ : imposes a duty to report criminal activity ${ }^{24}$ and blackmail is allowed;

JURISDICTION $B: \quad$ imposes a duty to report criminal activity and blackmail is prohibited;

JURISDICTION C: imposes no duty to report criminal activity and blackmail is allowed;

JURISDICTION $D: \quad$ imposes no duty to report criminal activity and blackmail is prohibited (the law in U.S. jurisdictions).

If a jurisdiction imposes a duty to report crime, as in Jurisdiction $A$, legalizing blackmail may have no effect on deterrence. In

level in order to preserve some marginal deterrence or because of constitutional constraints.

${ }^{23}$ See Landes \& Posner, supra note 8, at $42-43$ (noting that the price paid to the blackmailer is keyed to the victim's ability to pay and not to the cost of punishment); Posner, supra note 3 , at 1821 (stating that in a situation where a victim has been duly punished, the only effect of blackmail would be to increase the punishment by the amount of the blackmail payment).

24 Professor Feinberg argues that this is or has been the state of the law in common law jurisdictions, as states enforced "misprision of felony" and "compounding" statutes. These laws prohibited the failure to report the commission of a crime and the "settling ... of a claim that was really the state's to make, since it involved criminal, not merely civil, violations." FEINBERG, supra note 3, at 243-44. For a modern-day application of similar concepts to a small community of lawyers in Illinois, see In re Himmel, 533 N.E.2d 790, 795-96 (Ill. 1988) (subjecting a lawyer to discipline for failure to report the ethical misconduct of another lawyer). Feinberg argues further that even in the absence of a legal duty to report crimes, a "civic duty" requires people to "cooperate with law enforcement," and the illegality of blackmail prevents people from profiting from violations of this "duty of citizenship." FEINBERG, supra note 3, at 244-45. For additional discussion of crime reporting, see infra note 27; see also George P. Fletcher, Blackmail: the Paradigmatic Crime, 141 U. PA. L. REv. 1617 (1993). 
such a place, blackmail would be illegal not per se but because it requires the blackmailer to violate the reporting law. Any activity that would constitute blackmail would already be outlawed as attempting or offering to violate the duty to report criminal activity. In Jurisdiction $A$, then, allowing blackmail would be inherently inconsistent with the reporting law, and strict enforcement of the reporting law would give citizens an incentive to impose costs on criminals through public rather than private means. Blackmail activity would not increase deterrence above the level achievable by imposing a duty to report. Even if blackmail were technically legal, people would not invest resources in gathering information that could be used to blackmail others, because any attempt to blackmail would itself be subject to criminal sanction under the reporting law. People would have less incentive to gain the information because they would be required to disclose it to the government, with no possibility for private gain. In effect, Jurisdiction $A$ would achieve the same level of deterrence as Jurisdiction $B$. In Jurisdiction $B$, as in Jurisdiction $A$, most people would have an incentive to report criminal behavior simply to avoid breaking the law. Because Jurisdiction $B$ prohibits blackmail, people would probably not invest resources to gather incriminating information. Therefore, most information turned over to police would be casually rather than deliberately acquired. ${ }^{25}$

Because Jurisdiction $C$ imposes no duty to report crime, some of the casually acquired information that would otherwise be reported in Jurisdictions $A$ and $B$ could be lost by the government. Because Jurisdiction $C$ allows blackmail, however, it enables people to capitalize on incriminating information and might induce some of the nonreporters to blackmail criminals. Thus, some of the casually acquired information lost to the government in Jurisdiction $C$ might nonetheless be used to impose costs on criminals. Without a duty to report, Jurisdiction $C$ cannot ensure that all casually acquired information about criminal activity will still be disclosed. Nevertheless, it could recapture some of the value of casually acquired information through blackmail practiced by some of the

${ }^{25}$ Of course, some people may have independent incentives to discover criminal behavior and may engage in some investigation to serve their own interests. Other people may feel an altruistic urge to eradicate crime in their neighborhoods and communities. Levels of such private investigative activity would presumably be lower, however, than they would be in jurisdictions that also provide economic incentives to investigators. 
citizens who choose not to report. Moreover, in a jurisdiction such as $C$ where blackmail is allowed, people might have an incentive to gather incriminating information. The amount of socially useful information about crime could increase if people undertake investigative activities and, when they discover a criminal, impose costs on the wrongdoer in the form of blackmail.

Further, in a jurisdiction where blackmail is allowed, some blackmailers might have an incentive to disclose crimes to the government when criminals refuse to pay the demanded blackmail. They might disclose in order to preserve a reputation as blackmailers who make good on threats. ${ }^{26}$ Future blackmail threats will be more credible if blackmailers report crimes when blackmailees refuse to pay. Blackmailers might also turn in the criminals they unsuccessfully blackmail more readily if they have no fear of facing criminal charges themselves. Thus, allowing blackmail need not mean that casually or deliberately acquired information about crime will be lost to the government completely. If some blackmailers have information that they would not have disclosed to the state in the absence of a reporting requirement, but are willing to disclose simply to preserve credibility for future blackmailing, legalizing blackmail could actually increase the disclosure of casually acquired information. If blackmailers turn over deliberately acquired information to authorities in order to make good on a threat, the government gains information that people would not have an incentive to produce (much less disclose) in jurisdictions where blackmail is illegal.

In sum, it appears that allowing blackmail might increase deterrence. How does the deterrence achieved by allowing blackmail compare to deterrence levels where blackmail is illegal? In Jurisdiction $D$, which would outlaw blackmail but not impose a reporting requirement, the state might achieve the least deterrence of all. Some people with casually acquired information might remain silent because the jurisdiction imposes no legal duty to report crime. ${ }^{27}$ Thus, some casually acquired information could

26 This reputational concern could be particularly important to repeat players who blackmail more than once, such as Richard Epstein's imagined "Blackmail, Inc." See Epstein, infra note 32.

${ }^{27}$ Some people may feel a moral duty to report, but that duty is not enforced in our current system. It is difficult to measure the extent to which people disregard that moral duty and fail to disclose crimes they know about. Much of police investigative work may proceed on tips by informants and accounts by victims and witnesses, but it is probably also true that many crimes go unreported 
be lost. And unlike Jurisdiction $C$, which may get some deterrence value from these nonreporters when they commit blackmail, Jurisdiction $D$ could lose any enforcement benefits from the nonreporters of casually acquired information. Moreover, in a jurisdiction where blackmail is illegal, most people would lack monetary incentives to acquire incriminating information. Thus, Jurisdiction $D$ would lose some of the deliberately acquired information that might enhance deterrence in Jurisdiction $C$.

Legal rules permitting or prohibiting blackmail ${ }^{28}$ could have

and such investigations are never even begun. Statistics compiled by the National Bureau of Justice Statistics in 1992 show that fewer than $40 \%$ of all criminal "victimizations" are reported to the police. See BUREAU OF JUSTICE STATISTICS, U.S. DEP'T OF JUSTICE, CRIMINAL VICTIMIZATION IN THE UNITED STATES, 1990, at 102 (1992); see also BUREAU OF JUSTICE STATISTICS, U.S. DEP'T OF JUSTICE, SOURCEBOOK OF CRIMINAL JUSTICE STATISTICS-1991, at 199 (Hindelang Criminal Justice Research Ctr. ed., 1992) (presenting results of a poll by the Roper Organization: When asked, "[i]f you knew someone was cheating on his income tax, would you be likely to report it to the tax authorities or stay out of it? $70 \%$ of the respondents said that they would "stay out of it." Similarly, when asked whether they would report a co-worker's theft of merchandise from a store to the management, only $60 \%$ said that they were "likely to report it.").

28 The following matrix summarizes the combined effects of rules pertaining to blackmail and crime reporting:

FIGURE I

\begin{tabular}{|c|c|c|c|}
\hline \multirow[b]{2}{*}{$\begin{array}{l}\text { Duty to } \\
\text { report }\end{array}$} & \multicolumn{3}{|c|}{ Blackmail prohibited } \\
\hline & $\begin{array}{l}\text { Legalized blackmail is } \\
\text { irrelevant. Duty to re- } \\
\text { port creates deterrence } \\
\text { because criminal must } \\
\text { assess probability that } \\
\text { another will report. }\end{array}$ & $\begin{array}{l}\text { Must report all casual- } \\
\text { ly acquired informa- } \\
\text { tion-should see same } \\
\text { deterrence level as in } \\
\text { A. }\end{array}$ & $\begin{array}{l}\text { Effect on } \\
\text { casually } \\
\text { acquired } \\
\text { information }\end{array}$ \\
\hline & $\begin{array}{l}\text { No incentive to gain } \\
\text { information because it } \\
\text { must be reported. }\end{array}$ & $\begin{array}{l}\text { No incentive to gain } \\
\text { information-same as } \\
A . \\
B\end{array}$ & $\begin{array}{l}\text { Effect on } \\
\text { deliberately } \\
\text { acquired } \\
\text { information }\end{array}$ \\
\hline
\end{tabular}


the most pronounced effect on incentives to acquire information deliberately, at some expense of time, energy, or other resources by the blackmailer. A jurisdiction that forbids blackmail creates fewer incentives for people to become informed about criminal activity than does a jurisdiction where blackmail is legal. This could decrease the probability of detection by private as well as public authorities, and, in turn, lower deterrence.

One response to the "best case" for blackmail is that a system of bounties will more effectively create incentives to collect incriminating information without imposing some of the potential social costs of blackmail. ${ }^{29}$ It is possible, however, that blackmail might be more efficient than bounties. Bounties impose transaction costs when the state serves as middle person-paying a bounty to the informant and then collecting a fine from the criminal once convicted. ${ }^{30}$ Blackmail would not impose this sort of transaction cost

\begin{tabular}{ll|ll}
\hline & $C$ & $D$ \\
$\begin{array}{l}\text { In absence of a duty to } \\
\text { report, people with casu- } \\
\text { ally acquired information } \\
\text { may remain silent, there- } \\
\text { by reducing deterrence. }\end{array}$ & $\begin{array}{l}\text { May get higher report- } \\
\text { ing level of casually } \\
\text { acquired information } \\
\text { than in } C \text {, because } \\
\text { there is no incentive } \\
\text { to use information pri- } \\
\text { vately. }\end{array}$ & $\begin{array}{l}\text { Effect on } \\
\text { casually } \\
\text { acquired } \\
\text { information }\end{array}$ \\
duty to & $\begin{array}{l}\text { Some nonreporters may } \\
\text { use their casually ac- } \\
\text { quired information to } \\
\text { blackmail, however, im- } \\
\text { posing some costs on } \\
\text { criminals, thereby con- } \\
\text { tributing to deterrence. }\end{array}$ & & \\
$\begin{array}{l}\text { Creates incentives for } \\
\text { people to deliberately } \\
\text { acquire information for } \\
\text { use in blackmail, and } \\
\text { could make up for some } \\
\text { loss of casually acquired } \\
\text { information. }\end{array}$ & $\begin{array}{ll}\text { No incentive to gain } \\
\text { information, so some } \\
\text { deterrence from delib- } \\
\text { erately acquired infor- } \\
\text { mation is lost. }\end{array}$ & $\begin{array}{l}\text { Effect on } \\
\text { deliberately } \\
\text { acquired } \\
\text { information }\end{array}$ \\
\end{tabular}

${ }^{29}$ See Steven Shavell, An Economic Analysis of Threats and Their Illegality: Blackmail Extortion, and Robbery, 141 U. PA. L. REv. 1877, 1901 (1993) (suggesting that the optimal way to increase the probability of punishment is a system of bounties which would encourage people to acquire and report information about crimes).

${ }^{30}$ It is not clear, of course, that the state would be able to extract a fine from a criminal ex post in the same way that a blackmailer could extract payment from a criminal ex ante. The costs of trial, attorney fees, etc., might deplete the criminal's resources so that the state could not reimburse itself for the bounty it paid- 
because the blackmailer could collect directly from the offender. More importantly, bounties might not be as effective as blackmail in stimulating production and use of deliberately acquired information. If people fail to report crime because they do not want to deal with law enforcement authorities, they are not necessarily more likely to want to deal with officials when a bounty is offered. Blackmail gives these nonreporters financial incentive to acquire and use incriminating information without the disincentive of dealing with authorities. In addition, in a system of bounties the state must determine the criterion for payment, and the would-be informant must calculate the probability of meeting that criterionwhether it is apprehension, arrest, or conviction. If conditions are placed on the payment, particularly conditions that are outside of the informant's control, the informant must discount the payoff from deliberately acquiring the incriminating information according to the probability of payment. As that probability decreases, a potential bounty hunter may be less likely to invest the time and money to develop the information.

Finally, assertions about the benefits of bounties may be easier to test than claims about the deterrence benefits of blackmail. Some jurisdictions or divisions of law enforcement do offer rewards or bounties. Have they affected the amount of crime that is reported?

Thus, it appears that allowing blackmail of criminals could increase the probability that information about crime will be discovered and used to raise potential criminals' costs. In this way, incriminating blackmail could be a productive activity that might withstand the concerns of scholars who press for continued criminalization.

again imposing additional costs on the state. On the other hand, the state might be a better collection agent than the blackmailer; the state would probably have to do less negotiating with the criminal than the blackmailer would, and the state has superior enforcement tools. To improve the blackmailer's enforcement capability, the state could recognize a right of action to enforce the blackmail agreement, but this goes considerably further than the affirmative defense discussed in this Article. Without such a right of enforcement, of course, the blackmailer's only recourse is to report the crimes of blackmailees who breach the agreement and refuse to pay. 


\section{The Dangers of Blackmail}

Legal scholars and philosophers have adopted two major lines of analysis about blackmail. Moral theorists examine the parts and structure of the blackmail transaction to identify some element that gives rise to criminality. The economic approach, on the other hand, is more physiological. By predicting the consequences of decriminalizing blackmail, these scholars attempt to identify the basis for continued criminal prohibitions of blackmail. ${ }^{31}$

\section{A. Economic Inefficiency of Blackmail ${ }^{32}$}

Some scholars argue that the illegality of blackmail gives people a disincentive to engage in socially undesirable or wasteful behavior.

${ }^{31}$ Jeffrie G. Murphy has described this dichotomy in another useful way. He contrasts a condemnation of blackmail based on "deontological moral principles" with one based on "teleological considerations of social policy-e.g., considerations of utility." Jeffrie G. Murphy, Blackmail: A Preliminary Inquiry, 63 MONIST 156, $162-63$ (1980).

${ }^{32}$ Blackmail could be economically inefficient simply because it involves coercion of the blackmailee. If one of the parties to the blackmail transaction could be said to be acting involuntarily, the assumption that voluntary transactions are wealth maximizing would render the blackmail transaction nonmaximizing and thus inefficient. David Owens questions the voluntariness of blackmail because he doubts that the blackmailee's agreement can be sufficiently well informed to be rational. See David Owens, Should Blackmail be Banned?, 63 PHIL. 501, 509 (1988) ("The blackmail victim] cannot be certain how many blackmail contracts they will have to strike or how much they will have to pay out to each blackmailer."); see also Ronald H. Coase, The 1987 McCorkle Lecture: Blackmail, 74 VA. L. REv. 655, 675 (1988) ("The victim is also likely to be uncertain about the blackmailer's real intentions."). Although Owens argues convincingly that substantial uncertainty infuses the blackmail transaction, he cannot explain why it is necessarily irrational for a criminal to pay off a blackmailer and avoid detection by authorities. As many commentators have pointed out, the blackmailee often consents to and even welcomes the chance to pay off a potential informer. See, e.g., Richard A. Epstein, Blackmail, Inc., 50 U. CHI. L. REV. 553, 558 (1983) ("II]f one person does not have the right to threaten actions ...., he has to act without giving warning. This in turn will work to the disadvantage of the other party, who is now deprived of the choice that the threat would have otherwise given him."); Murphy, supra note 31, at 159 ( $^{a}[\mathrm{I}] \mathrm{n}$ many cases the person being blackmailed is willing to pay the asked price, and far prefers paying the price to having the blackmailer expose him. ..."). That the blackmailee may be faced with a hard choice between the consequences of disclosure and paying the blackmailer does not necessarily make the blackmail any more coercive than the choice facing many parties to wholly legitimate economic transactions. See Lindgren, supra note 3, at 701 \& n.162 ("Even highly coercive threats are present in many types of legitimate economic bargaining."); Murphy, supra note 31 , at 157 (stating that blackmail draws intoquestion "the morality of a whole range of economic transactions"). For a discussion of coercion in blackmail from a moral rather than an economic perspective, see generally Scott 
Ronald Coase, for example, has suggested that blackmail is illegal because it causes a wasteful expenditure of resources by the blackmailer. ${ }^{33}$ The blackmailer spends time and money to uncover information only to suppress it once the blackmailee makes the payoff. In Coase's view, this transaction produces nothing of value: "[I]t is obviously undesirable that resources should be devoted to bargaining which produces a situation no better than it was previously. ${ }^{n 4}$ Outlawing blackmail prevents or at least reduces this inefficient allocation of resources.

Professor Lindgren criticizes Coase's theory for failing to explain why blackmail should be illegal when the blackmailer acquires the information casually and therefore expends no resources in gathering the information. ${ }^{35}$ In these cases, the only costs are the transaction costs involved in negotiating with the blackmailee. ${ }^{36}$ As Lindgren points out, these costs are not necessarily wasteful, because the blackmailer and criminal will reach agreement in those negotiations only if each expects a net gain "large enough to offset the transaction costs of bargaining. ${ }^{37}$ In short, Lindgren accepts the power of Coase's theory to explain the illegality of blackmail based on information that is deliberately acquired, but argues that the costs of blackmail based on casually acquired information might be outweighed by a net private gain enjoyed by the parties to the blackmail transaction, and that Coase's attempt to base the illegality of blackmail on some "inefficiency" or "waste" inherent in the transaction is not persuasive. ${ }^{38}$

Altman, A Patchwork Theory of Blackmail, 141 U. PA. L. REv. 1639, 1640-43 (1993).

${ }^{33}$ See Coase, supra note 32, at 674 ("Blackmail involves the expenditure of resources in the collection of information which, on payment of blackmail, will be suppressed. It would be better if this information were not collected and the resources were used to produce something of value."); see also Ginsburg \&e Shechtman, supra note 4, at 1860 ("No rational economic planner would tolerate the existence of an industry dedicated to digging up dirt at real resource cost, and then reburying it."); Shavell, supra note 29, at 1894 ("[E]ffort expended by threateners is a social waste .... Similarly, precautions taken by potential victims avoiding threats reduce social welfare.").

34 Coase, supra note 32 , at 671.

35 See James Lindgren, Blackmail: On Waste, Morals, and Ronald Coase, 96 UCLA L. REV. 597, 601 (1989) ("The problem with the Coase-Ginsburg approach is that it is unable to explain why it is blackmail to sell information that is not purposefully acquired.").

${ }^{36}$ See Coase, supra note 32 , at 674 (stating that even when acquiring information requires no resources, "resources would certainly be employed in the blackmailing transaction").

${ }^{37}$ Lindgren, supra note 35 , at 602.

${ }^{38}$ See id. (" $[\mathrm{T}]$ he mere expenditure of resources does not render the bargain 
Coase's theory fails to explain the illegality of blackmail not only when it is based on casually acquired information, but also when it is based on deliberately acquired information. Coase may be incorrect when he assumes that the blackmail transaction is not productive. The blackmail transaction, or perhaps more accurately the fact that such a transaction is permitted, may produce a social good-deterrence. ${ }^{39}$ When the blackmail is based on incriminating information, it may augment the potential costs of criminal activity and deter crime, thereby increasing social welfare. ${ }^{40}$ The resources spent on discovering the blackmailee's criminal activity and negotiating with the criminal about the blackmail are not wasted if the social benefits from deterrence outweigh the costs of achieving it. But the word "deterrence" never appears in Coase's article, and he fails to consider the positive externalities that the blackmail transaction (or the potential for it) might produce. Coase incorrectly assumes that the resources spent on blackmail could be put to better use in all cases.

The conduct Coase deems most wasteful-blackmail based on deliberately acquired information-is the sort of activity most likely to add substantially to the costs of crime. When blackmail is illegal and people casually acquire information about criminal activity, some of the time (due to civic virtue, malice toward the criminal, or fear for their own security, etc.) people will disclose the crime to the authorities. Some of the deterrence achievable through blackmail

wasteful.").

${ }^{39}$ Professors Robert Cooter and Thomas Ulen have drawn a useful distinction between "productive facts" ("information that can be used to increase wealth") and "redistributive facts" ("information creating a bargaining advantage that can be used to redistribute wealth in favor of the knowledgeable party but that does not lead to the creation of new wealth"). COOTER \& ULEN, supra note 14, at 259. Although the law might efficiently create incentives for discovery of productive facts by compensating the discoverer, efficiency does not require compensation of those who discover redistributive facts. Furthermore, "allowing the discoverers of redistributive facts to use them to transfer wealth to themselves induces defensive expenditures on the part of parties seeking to avoid losing their wealth to more knowledgeable people, and these defensive expenditures are wasteful from a social viewpoint." Id. To the extent that people know that their criminal activity is subject to the costs of lawful blackmail, their activity is deterred, thus yielding blackmail that could be characterized as a "productive fact" and making it efficient to create incentives for its discovery.

40 There are exceptions to this assertion, of course. Some crime may benefit the criminal more than it harms anyone else. Reduction of such crimes would not necessarily increase social welfare. 
based on casually acquired information, therefore, could also be captured in a regime where blackmail is illegal. The potential deterrence from blackmail based on deliberately acquired information, on the other hand, might be lost entirely in a jurisdiction where blackmail is illegal. The expenditure of resources on investigation and negotiation, ${ }^{41}$ so wasteful in Coase's view, might not occur at all, because the criminalization of blackmail will reduce incentives to undertake such activity.

William Landes and Richard Posner would approve of such a result. They argue that a public monopoly on law enforcement leads to the optimal level of criminal law enforcement activity. Allowing blackmail, they say, would allow private enforcement of the law to compete with and effectively undermine the public monopoly on criminal law enforcement. ${ }^{42}$

Landes and Posner warn that blackmail could undercut public enforcement in ways that would lead to an underdeterrence of crime. The blackmailer might impose less than the optimal penalty on the criminal when the criminal is unable to pay the optimal penalty. In such circumstances, the state can incarcerate the offender to exact punishment, but the blackmailer can impose only monetary sanctions on the criminal. If "the blackmailer [sells] his incriminating information to the offender for a price lower than the statutory cost of punishment to the criminal, [the blackmail] would reduce the effective cost of punishment to the criminal below the level set by the legislature. ${ }^{43}$

Landes's and Posner's underenforcement theory seems to rest on three assumptions: 1) criminals have inadequate resources to

11 Granted, creating incentives to gain information for use in blackmail could impose social costs in the form of increased privacy invasions. Rewards or bounties for information about criminals might also encourage privacy violations, and yet bounties are not condemned for imposing heavy social costs. Such social costs may outweigh the deterrence benefits of blackmail, but this empirical point is different from Coase's assertion that blackmail produces nothing of value. Moreover, if the legislature considered the potential for privacy invasions when deciding which crimes to include in the affirmative defense, they might encourage incriminating blackmail only in contexts where privacy invasions are not likely to occur or be harmful. For additional comparison of bounties and blackmail, see Shavell, supra note 29, at 1901; see also supra text accompanying notes 29-30.

${ }^{42}$ See Landes \& Posner, supra note 8, at $42-43$ ("Were blackmail a form of private enforcement, lawful, the public monopoly of enforcement would be undermined.").

${ }^{43} \mathrm{Id}$. at 42. 
pay the blackmailer an appropriate fine, 2) blackmail is based only on casually acquired information, and 3) the casually acquired information that is used in blackmail would be turned over to the authorities if the blackmail did not occur. If any of these assumptions is suspended, the underenforcement thesis is weakened.

If the blackmailee is not poor and can afford the appropriate blackmail payment, then incarceration might not be necessary to deter. According to Landes and Posner, deterrence will be achievable by exacting the optimal penalty from criminals who have the means to pay. The deterrence stems from the fact that the criminal parts with the money, not that the state (as opposed to a private agent) collects it. Thus, when the criminal does not suffer significant wealth constraints, the underdeterrence Landes and Posner fear is not likely to occur. Even if the offender is too poor to pay the blackmailer the monetary equivalent of the incarceration he faces at the hands of public enforcers, any blackmail payment he can afford could simply supplement public enforcement. The state can still incarcerate the offender if he is apprehended.

If the information was deliberately rather than casually acquired, the blackmailer has added to the criminal's probability of being caught, and this increased probability of private detection may outweigh the slight drop in the probability of public detection due to the loss of the blackmailer as an informant to police. But has the government really lost the blackmailer as an informant? If the optimal fine has been set according to a probability of detection that assumes only the government is deliberately acquiring information, the blackmailer may increase that probability of detection by also deliberately acquiring information about the crime. The government can conduct its ordinary investigative activities; the blackmailer merely undertakes an additional to acquire information the government would not expect to get from the blackmailer anyway. ${ }^{44}$

Even if the blackmailer uses casually acquired information, the blackmail decreases the state's probability of apprehending and imprisoning the criminal only if the blackmailer would have disclosed the information to authorities if blackmail were illegal. If

44 If law enforcement authorities pay bounties to people who report crimes, they may assume that some deliberately acquired information will come from the public. If punishment is set based on probabilities of detection that depend upon "bounty hunters," then the blackmailer might decrease the probability of public detection. 
the blackmailer is exploiting casually acquired information that would not have been disclosed to authorities even if blackmail were illegal, ${ }^{45}$ the blackmailer is increasing the criminal's costs without decreasing the probability of public apprehension and enforcement. Even if some blackmail is based on casually acquired information that would have been reported to officials if blackmail were illegal, the resulting decrease in the probability of public detection might still be outweighed by the increased probability of private detection and punishment by private blackmailers with casually and deliberately acquired information.

Discounted blackmail payments will cause underdeterrence, then, only if together with public enforcement they cause the total costs imposed on criminals to decrease. Granted, legalizing incriminating blackmail will allow some individuals to profit from casually acquired information that they would have disclosed to the police if blackmail were illegal. This does not mean, however, that total deterrence will decrease. Those blackmailers might extract close to the optimal penalty from blackmailees who can afford it. Even if the blackmailers reduce the blackmail payment to account for the blackmailee's limited means, the loss in deterrence from this sort of blackmail might be outweighed by deterrence gains from blackmail by people with deliberately acquired information, or casually acquired information that would not be turned over to police if blackmail were illegal.

In addition to their underdeterrence hypothesis, Landes and Posner argue that blackmail could lead to overenforcement under two sets of circumstances. First, they fear that a private enforcer would not exercise discretionary nonenforcement that is typical of public prosecutors and law enforcers. ${ }^{46}$ Second, criminals may overpay by giving the blackmailer something close to the optimal fine even though they remain subject to public law enforcement.

Landes and Posner argue that public prosecutors would decline to prosecute cases that technically fall within a statute's prohibitions but do not create the social evils contemplated by the statute. Laws may be written broadly only because more tailored statutes would not be cost justified. With such statutes, the legislature relies on the

15 This category of information may be rather large. See supra note 27.

${ }^{16}$ See Landes \& Posner, supra note 8, at 38-39 ("Our analysis of private enforcement is relevant to the question [of discretionary nonenforcement] since it is clear that enforcer nullification would not be a feature of private enforcement: all laws would be enforced that yielded a positive expected net return."). 
people responsible for implementation to exercise some discretion in the enforcement of the law. ${ }^{47}$ Landes and Posner fear that private law enforcers would have an incentive to enforce laws whenever possible, lacking the insightful restraint of public enforcers. ${ }^{48}$

Landes's and Posner's fear of overenforcement of the law fails to account for the extent to which the probability of prosecution can affect the blackmailer's demand. Consider a case in which a) the prosecutor can only learn about the crime from the blackmailer; $;^{49}$ b) the probability that an informed prosecutor will proceed against a criminal is only fifty percent; and c) if prosecuted, the criminal will face a fine of $\$ 100,000$. Will the blackmailer overcharge the criminal who commits a crime subject to prosecutorial discretion? To answer this, we should consider how much a blackmailer would be able to extract from a criminal if the blackmailer learns about the violation and attempts blackmail.

Suppose that $C$ has committed a crime and $B$ learns about it, either by chance or through some effort. $B$ then approaches $C$ and proposes the blackmail amount $b^{*}$, to prevent disclosure. ${ }^{50} C$ will

${ }^{47}$ Decriminalizing blackmail in the manner considered in this Article would not necessarily trigger Landes's and Posner's fears of overenforcement. The legislature could specify the classes of criminals that it will permit to be blackmailed. This sort of specificity by the legislature would prevent situations from arising in which a blackmailer would inappropriately override a declination policy of a local prosecutor. If the blackmailer is blackmailing a criminal engaged in a crime covered by the affirmative defense, the legislature has already made clear its desire to deter that crime and has, in effect, overruled the prosecutor's informal declination policy, as legislatures often do. When legislatures specifically earmark funds for increased enforcement of drug laws, for example, they may effectively override prosecutors' informal policies of relaxed enforcement. A prosecutor would not necessarily object to circumvention of his or her declination policies through blackmail. The prosecutor might be declining to prosecute certain kinds of violations in order to preserve public resources, and not as a signal that those violations are condoned. Because blackmail would consume resources of the criminal, not the state, it would not undermine a declination policy based on fiscal conservation. Granted, this argument does not completely answer Landes's and Posner's concern about declination policies; rather, it shows that it may be possible from an operational perspective to get some of blackmail's benefits without the overdeterrence cost that Landes and Posner anticipate.

${ }^{48}$ See Landes \& Posner, supra note 8, at 38-39.

49 Prosecutors might have an independent probability to discover the crime without affecting this analysis.

${ }^{50}$ Here we suppose that $B$ has all the bargaining power and is therefore able to make a take-it-or-leave-it offer. Under alternative assumptions about bargaining power, the blackmail amount would be even lower, indicating that Landes's and Posner's concern with overdeterrence is even more misplaced. 
either accept or reject $B$ 's proposal. If $C$ accepts, the two will come to agreement and the negotiation will end: $C$, the blackmailee, will lose $b^{*}$, the value of the blackmail payment, and the blackmailer will gain $b^{*} .^{51}$ If $C$ rejects the blackmail transaction, $B$ will disclose the violation to $P$, the prosecutor, who will prosecute $50 \%$ of the time. If $P$ does not prosecute, the events will come to a close without payoffs to either party. If $C$ is prosecuted and punished, the payoff will be a negative one for $C$. $C$ will lose $\$ 100,000$ and the blackmailer will gain nothing.

$C$ 's strategy for accepting or rejecting the blackmail transaction will turn upon C's comparison of the payoffs from each alternative course of action. Since $C$ 's expected payoff from rejecting is $\$ 50,000, C$ will rationally accept a blackmail transaction if and only if $B$ demands less than $\$ 50,000$. If $B$ knows that this is $C$ 's optimal strategy, $B$ will demand such an amount (e.g., \$49,999). This example shows that allowing blackmail will not necessarily overdeter when prosecutors exercise discretion to decline prosecution of the blackmailee's crime. In the absence of blackmail, the expected costs of the crime to $C$ are $\$ 50,000$. Where blackmail is allowed, the expected costs will be just shy of that amount (e.g., $\$ 49,999) .^{52}$

Landes and Posner also argue that blackmail may cause overenforcement of the law if the blackmailee pays a blackmailer the full fine she would expect to pay under public enforcement when she may still be subject to further punishment by public enforcers. ${ }^{53}$ Yet their argument again ignores the possibility that further

51 Transaction costs are assumed to be zero.

52 This order of events can be illustrated by the following game tree:

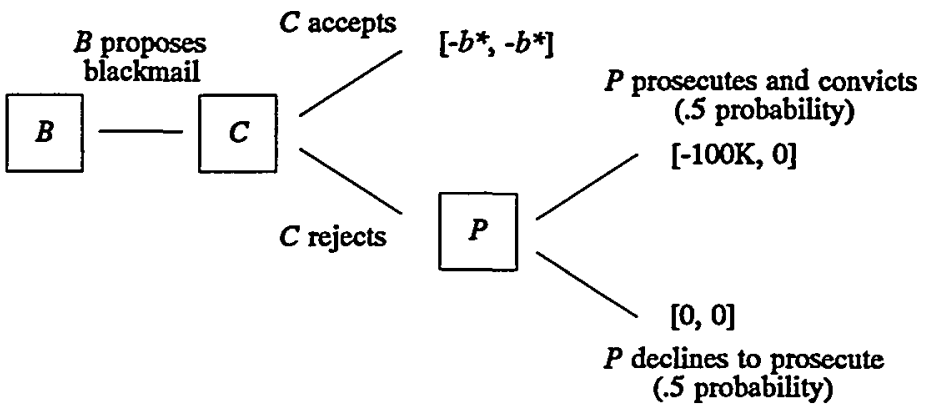

Payoffs: $[C$ (Criminal), $B$ (Blackmailer) $]$ Fine $=\$ 100,000$ $C$ 's expected cost of rejecting blackmail $=(-\$ 100,000)(.5)=-\$ 50,000$

53 See Landes \& Posner, supra note 8, at 42; see also Lindgren, supra note 85 , at 606 n.32 (noting that a criminal calculating how much to pay a blackmailer must discount the amount by the probability someone else will discover the information, 
public enforcement could affect the maximum amount blackmailers can extract from criminals. A similar game theoretic model can be constructed to show how the possibility of future enforcement will reduce the maximum amount that a blackmailer can charge. The adjustability of the blackmail fee is a natural check against their overenforcement arguments. The legalization of blackmail, therefore, can increase the chance that information about crime will be produced and used to impose costs on criminals (hence, increasing deterrence) without giving rise to concerns that blackmailers will be able to extract more than the socially optimal amount. Blackmailers and criminals are, in a real sense, "bargaining in the shadow of the law ${ }^{\text {54 }}$ and are unlikely to strike deals outside the law's penumbra.

Richard Epstein analyzes blackmail instrumentally by asking, "what would the world look like if blackmail were legalized?"55 If blackmail were legal, Epstein argues, blackmailers would gain incentives to engage in ancillary crime or fraud; blackmail has a "necessary tendency to induce deception and other wrongs." The interaction between blackmailer and criminal may not be coercive in itself, Epstein asserts, but it will occur in a context "rife with coercive and fraudulent elements. ${ }^{57}$

Epstein does not seem to argue that the blackmailer is committing fraud by failing to disclose the crime. ${ }^{58}$ Instead, he is con-

that the blackmailer might ask for more money in the future, that the blackmailer will carry out the threat even if paid, and that the blackmailer's threat is an empty one); Owens, supra note 32, at 511-13 (arguing that blackmail should be illegal because it is an "irrational bargain;" blackmailees lack adequate information about whether the blackmailer will carry out the threat, whether they will be subject to future threats, and what the amount of those future demands might be). Overenforcement of the law is an undesirable result if we assume that some crime is efficient and should not be deterred. Mitchell Polinsky illustrates the possibility of efficient crime with an example-double parking. In some emergency situations, the benefits from double parking might outweigh the costs it imposes on others. See POLINSKY, supra note 14, at 75-76. Of course, if the legislature promulgates a list of crimes that will be subject to blackmail, then the legislature presumably makes a judgment that the benefits of deterring those crimes outweigh the cost that an efficient crime might also be deterred.

${ }^{54}$ Robert H. Mnookin \& Lewis Kornhauser, Bargaining in the Shadow of the Law: The Case of Divorce, 88 YALE L.J. 950, 950 (1979) (discussing "negotiations and bargaining that occur outside the courtroom").

55 Epstein, supra note 32, at 562.

${ }^{56}$ Id. at 565 .

57 Id. at 566.

58 James Lindgren says that "[t]o make any sense," Epstein's theory must be premised on a belief that through blackmail alone, the blackmailer engages in 
cerned that the blackmail aggravates ongoing fraud by the blackmailee against a third party. The blackmailee is avoiding punishment or other sanctions from third parties by hiding the incriminating information. Epstein says that a blackmailer will facilitate the blackmail by counseling the blackmailee about "the proper way to arrange his affairs in order to keep the disclosures from being made."59 Thus the blackmailer will "participate in the very fraud" the blackmailee is committing against a third party. ${ }^{60}$

Epstein's fraud theory takes a strange turn when applied to blackmail based on incriminating information. Any criminal eluding public authorities could be said to be engaged in fraudulent activity, pretending to be law-abiding when in fact she has committed a crime. According to Epstein's theory, any criminal who fails to surrender to police immediately would be perpetrating fraud in addition to the actual crime. People who learn of the crime and fail to report it could also fall into Epstein's group of fraudulent actors. A principled distinction can be drawn, however, between passively waiting for the state to locate a criminal and failing to cooperate with officials candidly when approached. Indeed, this distinction may be reflected in the law regarding obstruction of justice, which becomes effective only after government proceedings, such as grand jury investigations, have begun. ${ }^{61}$

Moreover, the blackmailer's obligations under the blackmail contract could be devised to distinguish clearly between: 1) the blackmailer's right affirmatively to disclose the criminal's crime to the authorities, which the blackmailer is promising not to exercise in exchange for the blackmail payment; and 2) the blackmailer's duty to cooperate with law enforcement officials and answer their questions truthfully if they should become aware of the criminal's illegal activity independent of the blackmailer. The parties could recognize the difference between a blackmailer's forbearance from actively seeking out authorities and disclosing the blackmailee's crime, on the one hand, and the blackmailer's passive, reactive cooperation with authorities should they seek her out at some point. If the blackmailer fails to cooperate with authorities should they

immoral or criminal concealment. Lindgren, supra note 7, at 914. Epstein's actual arguments, however, seem to focus much more on the ways a blackmailer "can" (and thus does not necessarily) take additional steps to facilitate the blackmailee's fraud of third parties.

${ }^{59}$ Epstein, supra note 32, at 564.

${ }^{60}$ Id.

61 See, e.g., 18 U.S.C. § 1510 (1988). 
approach her, she advances beyond silence in exchange for payment and starts to engage in affirmative concealment of the crime. The affirmative defense of incriminating blackmail considered in this Article does not contemplate that the blackmailer should be able to take actions to reduce the probability of detection of the crime by authorities, except to the extent that failure to act as an informant in a proactive way reduces probability of detection by authorities.

The blackmail transaction could not include an agreement that the blackmailer would thwart government investigation of the blackmailee by affirmatively concealing the crime or refusing to cooperate with authorities. ${ }^{62}$ To invoke the affirmative defense that the blackmailee was a criminal and the blackmailer was a private law enforcer, the blackmailer would have to show that he was reasonably certain about the blackmailee's criminal activity. Evidence that the blackmailer expressed ignorance of the crime to authorities or to the victim ${ }^{63}$ in the wake of the blackmail would demonstrate concealment, since it would directly contradict the defendant's position in presenting the affirmative defense.

Epstein also fears that legalized blackmail will spawn additional criminal activity by the blackmailee. If blackmailees lack the resources to make blackmail payments, they will be driven to illegal activity because they will be unable to borrow money without revealing the reason for the loan. ${ }^{64}$ As Professor Lindgren points out in his response to Epstein, however, we do not generally criminalize activities simply because they are paid for with illegal

${ }^{62}$ It is possible, of course, that unless the blackmailer promises to lie to authorities or otherwise refuses to cooperate, criminals will be unwilling to pay blackmail. In other words, the mere promise to forego affirmative disclosure to the police may not generate much income for a potential blackmailer. We cannot know at this point how the value of total silence would compare to the value of limited silence, and how much, if anything, criminals will be willing to pay for the latter. Such logistical problems may explain why these transactions will be rare. They do not, however, explain why the promise to keep the more limited silence should be illegal.

63 The blackmailer's failure to report the crime will make it more difficult for the victim to recover from the criminal in a civil action, but this negative effect is not enough to justify criminalizing blackmail. Under the present system, people have no duty to report a crime to authorities; nor do they have a duty to disclose the identity of tortfeasors to their victims. Blackmailers could remain subject to liability for fraud if they affirmatively misrepresent what they know when asked by the victim or the victim's representatives. In any case, the blackmail would not necessarily decrease the victim's probability of discovering the identity of the tortfeasor.

${ }^{64}$ See Epstein, supra note 32, at 564. 
gains. People often commit crimes to pay for legitimate goods and services, but that is not a rationale for criminalizing the production of those items. ${ }^{65}$ Moreover, even people engaged in legitimate activities may misrepresent the reason for a loan if they are embarrassed about the true purpose. ${ }^{66}$

Even if, as Epstein asserts, fraud against third parties is a "precondition" of blackmail that justifies its illegality, he overlooks the possibility that potential third parties as a group might benefit if blackmail were legal and deterred criminal activity. The fewer crimes that occurred, the less fraud would be necessary to conceal the crimes. The social benefits from such deterrence might outweigh any costs associated with the "fraud" Epstein predicts. If the government shares the right to collect fines with blackmailers because it predicts additional deterrence from their activity, the concealment of crimes that have already occurred might not be considered harmful to the government's interests, as Epstein seems to assume it will be.

Epstein's theory of blackmail, if somewhat incomplete, nonetheless reveals a possible problem with the affirmative defense discussed in this Article. In our zeal to deter one set of crimes, we might create incentives to commit others. The blackmailer could turn out to be as dangerous as the criminal with whom he transacts business. Because actual or potential physical force is part of many crimes, many blackmailers will have to be prepared to deal with violent blackmailees. It might prove difficult to know when blackmailers are merely prepared for violence and when they initiate it.

Monitoring blackmailers' activities would be difficult, and they might use criminal methods to operate an otherwise legitimate business. For example, a blackmailer might approach a criminal and threaten not only to disclose incriminating information to the authorities unless paid, but also to harm the criminal's person or property. The criminal is unlikely to report the illegal threat, because she will fear detection of her criminal activity if she goes to the authorities.

The possibility that the blackmailer will commit crimes may not be as great a problem as it initially appears, however. The concern

${ }^{65}$ See Lindgren, supra note 7, at 920-21.

${ }^{66}$ See id. at 921 (noting that "if a potential defendant is borrowing to pay to avoid an embarrassing lawsuit, he will try to conceal the real reason for the loanwhether it is a legitimate settlement or blackmail"). 
about violence might be addressed by a legislative proposal that crimes associated with violence would be excluded from the affirmative defense. Moreover, if a blackmailer were going to supplement threats to disclose incriminating information with threats of violence, she would be just as likely to do so in the present system where both threats are illegal as in a system providing an affirmative defense of incriminating blackmail. Indeed, if people could legitimately profit from incriminating blackmail, they might feel an increased incentive to limit their threats to the legal kind. ${ }^{67}$ Under the present system, having already crossed the line of illegality in delivering the threat to disclose the blackmailee's crime, the blackmailer may feel less hesitant to go further and deliver other threats, such as threats to harm persons, destroy property, or disclose information that is embarrassing but not incriminating. ${ }^{68}$

In sum, an economic analysis of blackmail raises important questions about the costs and benefits of incriminating blackmail. The costs of such blackmail would not clearly outweigh the deterrence benefits, and economists who have analyzed blackmail have failed to consider the benefits from generating and using increased amounts of incriminating information, both casually and deliberately acquired. If a more complete economic analysis finds benefits that may outweigh admitted costs, then the illegality of blackmail must find its basis in something other than strict efficiency.

${ }^{67}$ Indeed, the blackmailers themselves will provide some self-policing. Knowing that the criminal activity of the blackmailee may later serve as a defense, the blackmailers will have an incentive to keep records of the amounts paid and the evidence on which they based their threats. They could even report their blackmail income to the IRS and still maintain the secrecy of their income source, much as lawyers report income from their practice generally, without submitting a list of clients. See Epstein, supra note 32, at 563 (comparing litigation about the blackmail contract to trade secret litigation, and noting that "the complications of blackmail are only those endemic to any complicated commercial transaction"). But see Roe v. United States, 781 F.2d 238, 248 (2d Cir. 1985) (en banc) (holding that "absent special circumstances ... disclosure of fee information and client identity is not privileged even though it might incriminate the client"), cert. denied, 475 U.S. 1108 (1986).

68 This could be viewed as a variation on the anti-gun control slogan about firearms: "if blackmail is criminal, only criminals will engage in blackmail." 


\section{B. Lindgren's Structural Theory of Blackmail:}

Equity and Externalities

It is blackmail's impact on third parties that most concerns James Lindgren. In his 1984 article, Unraveling the Paradox of Blackmail, ${ }^{69}$ Professor Lindgren offers a structural theory of blackmail that straddles the boundary between economic and moral theories. The "key" to explaining the criminality of blackmail, he asserts, is its "triangular" structure. ${ }^{70}$ The blackmail transaction involves not only the blackmailer and the victim, but a third party as well. ${ }^{71}$ In the case of blackmail involving incriminating information, the third party is the public at large or law enforcement authorities. ${ }^{72}$ "If the blackmail victim pays the blackmailer, it is to avoid the harm that those others would inflict. . . To get what he wants, the blackmailer uses leverage that is less his than someone else's. Selling the right to go to the police involves suppressing the state's interests. ${ }^{n 3}$ Thus, Lindgren argues, the criminalization of blackmail reflects "a principled decision that advantages may not be gained by extra leverage belonging more to a third party than to the threatener. ${ }^{74}$

Lindgren would outlaw blackmail because it harms third parties by compromising their rights. ${ }^{75} \mathrm{He}$ thus focuses on blackmail's externalities, but overlooks the fact that those externalities could be positive as well as negative. An economic analysis of blackmail's costs and benefits-including these spillover effects, both positive and negative-might not lead to the conclusion that blackmail should be illegal. ${ }^{76}$ Realizing this, perhaps, Lindgren expresses his concern for third party effects in terms of equity rather than efficiency. Although Lindgren claims that " $[t]$ he problem is not with anything intrinsic to the threat, or any other aspect of the

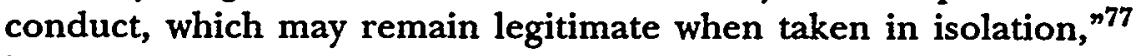
he is really objecting to the blackmailer's unjust enrichment from

${ }^{69}$ Lindgren, supra note 3.

$70 \mathrm{Id}$. at 672-73.

71 See id. at 672 .

72 See id.

73 Id.

74 Id.

75 See Posner, supra note 3, at 1818 ("Economists are troubled by prohibitions against voluntary transactions unless the transactions impose involuntary costs on third parties."); see also supra note $\mathbf{3 2}$ (discussing coercion and efficiency).

76 See Lindgren, supra note 3 , at 670-71.

77 Id. at 717 . 
leverage that is not his to use: “[T]he blackmailer's own interest is not sufficient to justify his using that leverage. Thus the leverage used, while legitimate in the hands of another, is illegitimate in the hands of the blackmailer. ${ }^{n 78}$

By calling the blackmailer an "unauthorized agent for the public,"79 Lindgren articulates in ethical terms a suggestion Landes and Posner made in economic terms: In the case of threats to disclose the blackmail victim's adultery, "[a] third party is not permitted to 'blackmail' the offending spouse (unless the third party is the victimized spouse's agent) because permitting him to enforce the marital contract would undermine the assignment of the exclusive right to enforce such contracts to the victim of the breach. ${ }^{80}$ Lindgren couches his analysis of blackmail in terms of the rights of the third party whose leverage is appropriated, but also emphasizes the fact that the blackmailer is collecting undeserved value through such appropriation. ${ }^{81}$

Externalities to the blackmail transaction might provide good reasons to regulate blackmail and account for the interests of people or entities who are not parties to the negotiation. The mere existence of externalities, however, is not a sufficient rationale for making blackmail illegal. Externalities can be both negative and positive. If the activity is otherwise beneficial, we should not assume that its costs-including effects on third parties-necessarily outweigh those benefits.

Just what are the externalities produced by the blackmail? Lindgren asserts that in the case of threats to disclose a crime, the blackmailer appropriates the power of the state by effectively threatening the blackmailee with prosecution unless the demands

${ }^{78}$ Id. Lindgren's theory could be seen as a refinement of the notion that blackmail is illegal because the threat is wrongful. By focusing on the appropriation of leverage from a third party, Lindgren presents an expanded view of what "the threat" entails. See id. Wrongfulness can arise as much from a sense of inequity (leverage wrongfully gained) as from the outright illegality of the threatened act. The blackmailer may threaten to disclose information that will lead the police to arrest the blackmailee. Included in that threat is the leverage created by the expected harm. The leverage cannot be separated from the words of the threat, for it is the leverage that gives the spoken words their intended weight. When Lindgren says that the appropriation of leverage is wrongful, he is presenting a new aspect of the threat that is wrongful.

${ }^{79}$ Id. at 715 .

${ }^{80}$ Landes \& Posner, supra note 8, at 43.

81 See FEINBERG, supra note 3, at 363 n.45 ("Even though James Lindgren gives central importance to protecting the rights of third parties . . . his major emphasis ... is on the unjust gain of the blackmailer."). 
are met. ${ }^{82}$ The "criminal processes" invoked by the blackmailer, however, are designed "not to settle private disputes but to protect the interests of the public at large. ${ }^{\text {} 83}$ But what are these interests of the public that the blackmailer compromises? Lindgren assumes a "disjunction" between the interests of the blackmailer and the "interests of third parties whose leverage he uses," ${ }^{84}$ but does not show that different interests necessarily lead to conflicting interests.

For example, Lindgren presents a hypothetical case of blackmail in which a woman threatens to disclose that a company is criminally violating pollution standards by using a smoke stack without pollution control equipment. She may live near the smokestack and suffer some damage from the pollution, for which she can seek some compensation. ${ }^{85}$ But if she asks for $\$ 1,000,000$ to keep quiet about the pollution and "seeks nothing for the public's benefit," Lindgren says, she has "clearly" committed blackmail. ${ }^{86}$ This is because " $[t]$ here is an almost total disjunction between the advantage sought and the leverage used. ${ }^{n 7}$

Lindgren's mistake is to see "public benefit" only in the short term. By failing to recognize that this woman's blackmail imposes costs on a wrongdoer that, if allowed, might deter other polluters because they fear similar treatment, Lindgren creates a greater "disjunction" between the interests of the blackmailer and the public than may actually exist. Particularly when the blackmail may confer some social benefits of deterrence, the exchange seems fair: the blackmailer "appropriates" the state's leverage but also creates some deterrence value that inures to the benefit of the general public. The public may, as Lindgren suggests, "prefer" that the blackmailer report the polluter, ${ }^{88}$ but they do not require it. As explained above, ${ }^{89}$ in the absence of a reporting requirement, the public might benefit more from incriminating information if blackmail is allowed.

In many cases, however, compromise of the state's claim is not the only externality of the blackmail transaction. Sometimes the

82 See Lindgren, supra note 3, at 717 ("Selling the right to go to the police involves suppressing the state's claim, bargaining with the state's chip.").

${ }^{83} \mathrm{Id}$. at 714 n.222.

84 Id. at 714.

${ }^{85}$ See id.

${ }^{86} \mathrm{Id}$. at 714-15.

${ }^{87} \mathrm{Id}$. at 715.

${ }^{88}$ See id.

${ }^{89}$ See supra text accompanying notes 24-30. 
blackmailer also appropriates the leverage of the victim of the crime, who might have a private right of action in tort against the blackmailee, or perhaps some right to restitution through the criminal justice system. The blackmailer does not so clearly create value that the victim of the crime can enjoy in exchange for the appropriated leverage. Indeed, the blackmailer may deplete the resources of the blackmailee so that the crime victim has a lower probability of ever collecting restitution or tort damages from the blackmail victim. ${ }^{90}$

If we take seriously the notion that blackmailers might confer social benefits by increasing the criminal's costs of crime, then we should consider the possibility that those benefits will outweigh the losses to individual victims who are unable to collect restitution from a criminal defendant who, but for the blackmail payments, would have been able to make restitution. Though some people who are actually the victims of crimes may be unable to collect restitution, other people who would have been victims of crime may be spared that fate because the criminal who would have harmed them was deterred by the specter of the increased costs of blackmail.

Lindgren's translation of economic theory to the language of equity is powerful, if not entirely illuminating. It suggests, moreover, that where the efficiency criterion fails to explain the illegality of incriminating blackmail, moral theory may step in to provide a more persuasive case for the prohibition.

\section{MORALITY ON A SYSTEMIC SCALE: AGAINST BlackMaIL}

This Article has attempted to present the best case for blackmail by limiting it to a narrow category of behavior and tailoring rules to maximize potential benefits from that behavior while minimizing the costs. Even this arguably productive form of blackmail seems wrongful, but economic theories of blackmail do not appear to capture this element of wrongfulness. Lindgren's triangular theory comes closer, but requires some additional moral analysis to flesh out the theory. Unfortunately, many moral theories of blackmail

${ }^{90}$ See Posner, supra note 3, at 1827. Knowing they are less likely to collect restitution or damages if victimized by crime could lead people to take wasteful precautions to prevent crimes. This effect could be countered, however, by the increased deterrent effect of blackmail. If people know they are less likely to become crime victims, they will feel less compelled to spend money on precautions. 
lose their force when the blackmailee is actually a lawbreaker, because the moral theories rest upon assumptions about preexisting rights to information, privacy, and peace that may not apply to criminals. ${ }^{91}$

To explain the illegality of incriminating blackmail, economic and moral theories must be modified or enriched by a sense of the community's collective interest in the administration of justice as a public event that binds and defines us. We are intuitively suspicious of private justice, and private justice is the essence of incriminating blackmail. To discover the aspect of blackmail that justifies its illegality, ${ }^{92}$ then, we need to consider further the problems with private justice generally and in the criminal context particularly.

To say that a public authority enforces the criminal law is to state a near tautology. Many define criminal prohibitions not just by the severity of their associated penalty, but also by the state's exclusive entitlement to enforce them. ${ }^{93}$ The criminal action

91 A multitude of moral theorists have attempted to resolve the paradox of blackmail. Several participants in this Symposium have contributed to this project. Space constraints do not allow me to give these theories the attention they deserve. See, e.g., Debra J. Campbell, Why Blackmail should be Criminalized: A Reply to Walter Block and David Gordon, 21 LoY. L.A. L. REV. 883, 888 (1988) (noting that blackmail is illegal because it presents the blackmailee with a "coerced choice" that requires the blackmailee to "choose between two things when he (the listener) has a legitimate claim to both things"; but noting also that in the case of incriminating blackmail the state or the victim of the blackmailee's crime might legitimately extract some value from the blackmailee, casting doubt upon Campbell's claim that the blackmailee has a "legitimate claim" to the money the blackmailer demands); FEINBERG, supra note 3, at 241, 243 (arguing that incriminating blackmail should be illegal because it requires the blackmailer to violate a duty to report crime; but also noting that the existence of such a duty is not at all clear); Wendy Gordon, Truth and Consequences: The Force of Blackmail's Central Case, 141 U. PA. L. REv. 1741 (1993) (basing the illegality of blackmail on the unjustified harm the blackmailer causes the blackmailee, and the fact that the blackmailer uses the blackmailee as an instrument to serve only the blackmailer's own selfish purposes; yet as this article suggests, the harm might be justified and the blackmailees might deserve the harm they suffer if they have committed crimes); Murphy, supra note 31, at 165 ("[W]e will not allow blackmail where the threat is to do something that a person not only has a right to do but should do-e.g., report crime to the police.").

92 Whether this troubling aspect is the "key" to blackmail's illegality (as Lindgren claims for his triangular theory of blackmail, see supra text accompanying note 70) or the basis for an "interesting distinction" between legitimate and illegitimate activities (as Murphy claims for his theory, see supra note 31) remains to be seen.

93 See 4 WILlIAM BLAckSTONe, COMMENTARIEs *8 ("Whatever power, therefore, individuals had of punishing offenses against the law of nature, that is now vested in the magistrate alone, who bears the sword of justice by the consent of the whole 
belongs not to the victim, but to the state. Such truisms about the nature of criminal law seem to lead inexorably to the conclusion that it should be enforced publicly rather than privately.

Current enforcement of the criminal law, however, is not always consistent with this emphasis on public enforcement. The "victim's rights" movement could be viewed as an attempt to recognize the private as well as the public interests at stake when criminal violations occur. ${ }^{94}$ "Restorative" justice similarly emphasizes the interests of crime victims and asserts that complete resolution of criminal conflicts is impossible without "reconciliation" between four parties: victim, offender, community and state. ${ }^{95}$

Victim-offender mediation ${ }^{96}$ is appropriately emblematic of the movement to recognize private interests in criminal law enforcement. In many ways the debate about privatizing the criminal law is consistent with the larger debate about alternative dispute resolution (ADR). ${ }^{97}$ Although ADR methods are much too varied

community.").

${ }^{94}$ See, e.g., Karyn E. Polito, The Rights of Crime Victims in the Criminal Justice System: Is Justice Blind to the Victims of Crime? 16 NEW ENG. J. ON CRIM. \& Crv. CONFINEMENT 241, 242 (1990) (arguing that victims of crime deserve the right of participation in the judicial process that the Constitution guarantees to defendants).

95 See Criminal Justice, Restrtution, AND Reconciliation (Burt Galaway \& Joe Hudson eds., 1990) (presenting a set of papers on restitution programming and restorative justice); MEDIATION \& CRIMINAL JUSTICE (Martin Wright \& Burt Galaway eds., 1989) (advocating victim/offender mediation); MARK UMBREIT, CRIME \& RECONCILIATION 98 (1985) (asserting that reconciliation can best be achieved through a face-to-face meeting between victim and offender); HowARD ZEHR, CHANGING LENSES 184 (1990) (describing the four basic dimensions of harm-to the victim, to interpersonal relationships, to the offenders, and to the community).

${ }_{96}$ Across the United States, many jurisdictions are implementing "VictimOffender Reconciliation Programs," which use mediation between victim and offender as a supplement to or substitute for adjudication in the criminal court. Approximately 100 such programs currently exist or are under development. See VICTIM-OFFENDER RECONCILIATION PROGRAM, VORP DIRECTORY (forthcoming 1993). In some of these programs, judges, prosecutors, or probation officers refer cases to mediation programs for resolution and exercise little or no oversight over the process or its results. They are a welcome relief for overburdened criminal dockets, but serious questions remain about the value of the process for victim, offender, and the public. Whether the programs contribute to or detract from deterrence is a particularly vexing question, and little evidence exists regarding recidivism rates for offender participants. But see Martin S. Rowley, Recidivism of Juvenile Offenders in a Diversion Restitution Program in CRIMINAL JUSTICE, RESTITUTION AND RECONCILIATION, supra note 95, at 217, 218 (noting that there is some evidence that successful completion of restitution by juveniles lowers recidivism rates).

${ }^{97}$ Alternative dispute resolution, or ADR, refers to the myriad of dispute 
to allow generalizations, they may be better suited to resolving private disputes than those having obvious public ramifications. ${ }^{98}$ Even civil matters may raise public issues and implicate public interests as cases between two private entities create spill-over effects. Cases that affect public interests may require public involvement through the court system. Resolving these cases privately may not satisfy the public need for oversight and input.

Several years ago Owen $M$. Fiss raised this concern in his article, Against Settlement. ${ }^{99}$ Professor Fiss complained that proponents of ADR "treat[] settlement as the anticipation of the outcome of trial and assume[] that the terms of settlement are simply a product of the parties' predictions of that outcome. ${ }^{n 100}$ According to Fiss, a settlement that anticipates an adjudicative outcome is inferior to actual adjudication because the settlement "is based on bargaining and accepts inequalities of wealth as an integral and legitimate component of the process" while adjudication "knowingly struggles against those inequalities."101 Fiss's hostility to settlement stems from his conception of justice, which is essentially and necessarily public:

Adjudication uses public resources, and employs not strangers chosen by the parties but public officials chosen by a process in which the public participates. These officials ... possess a power that has been defined and conferred by public law, not by private agreement . . . . to explicate and give force to the values embodied in authoritative texts such as the Constitution and statutes: to

resolution techniques that are used to facilitate or obviate adjudication in the courts. Such methods include negotiation, mediation, arbitration, mini-trials, and early neutral evaluation of disputes. See generally STEPHEN B. GOLDBERG ET AL., DISPUTE RESOLUTION (2d ed. 1992) (providing a "taxonomy" of dispute resolution and background information regarding various methods). "Alternative dispute resolution" may be a misnomer, since fewer than $10 \%$ of all cases filed actually go to trial. See id.; see also Carrie Menkel-Meadow, Dispute Resolution: The Periphery Becomes the Core, 69 JUDICATURE 300, 300 (1986) (reviewing STEVEN GoLDBERG ET AL., supra). Because any private method of dispute resolution proceeds "in the shadow of the law," one might, however, accurately characterize such methods as alternatives to adjudication, which underlies them all. See Mnookin \& Kornhauser, supra note 54, at 951-52.

98 Obviously, this cannot be absolutely true. Mediation has proven to be a constructive (and often successful) method of resolving large-scale public policy debates, such as environmental or land use disputes. The federal government has encouraged many of its agencies to use negotiation and mediation even as they establish administrative rules and regulations.

${ }^{99}$ Owen M. Fiss, Against Settlement, 93 YALE L. J. 1073 (1984).

100 Id. at 1076.

${ }^{101} I d$. at 1078. 
interpret those values and to bring reality into accord with them. ${ }^{102}$

Because he believes that many civil cases require such authoritative interpretation and declaration of public values, Fiss is unwilling to consign any cases to private resolution.

Incriminating blackmail raises the specter of Fiss's greatest fears about private justice. Resource disparities will affect outcomes in blackmail powerfully. Legalized blackmail allows wealthy criminals to prevent (or at least postpone) disclosure of their crimes by purchasing the blackmailer's silence. Poorer criminals lack this purchasing power, and are thus more likely to be reported, apprehended, and imprisoned. The economic model of deterrence outlined earlier in this Article suggests that monetary penalties and imprisonment are fungible. Thus monetary penalties alone may be sufficient to deter criminals who actually have money to lose, but insufficient to deter criminals who lack resources to pay. The theoretical differences in deterrence, however, cannot outweigh the overwhelming sense that punishing criminals differently based on wealth is inherently unfair. ${ }^{103}$

As Professor Lindgren has suggested, a blackmailer with information about a crime compromises the public interest when he takes money to keep silent, but we need to describe that public interest more fully to understand whether the blackmailer is doing any real harm by "bargaining with the state's chip." 104 The point is not just that the blackmailer attempts to step into the shoes of the state to bargain with the criminal; the problem is that those shoes will never fit. Even if the blackmailer carefully calculates the likely outcome if the crime is reported, he cannot perform one of the state's most important tasks in articulating and enforcing the criminal law: declaring societal norms in public and labeling as

$102 I d$. at 1085.

${ }^{103}$ It seemed that way to the U.S. Supreme Court, and in Tate v. Short, 401 U.S. 395 (1971), the Court struck down a sentencing scheme that required convicted criminals who were unable to pay a fine immediately to spend time in prison. See also Williams v. Illinois, 399 U.S. 235, 244 (1970) ("[T]he Equal Protection Clause of the Fourteenth Amendment requires that the statutory ceiling placed on imprisonment for any substantive offense be the same for all defendants irrespective of their economic status."). But see ECONOMIC ANALYSIS OF LAW, supra note 14, at 209 ("Since fines and imprisonment are simply different ways of imposing disutility on violators, the Supreme Court is wrong to regard a sentence that imposes a fine but provides for imprisonment if the defendant cannot or will not pay the fine as discriminating against the poor.").

104 Lindgren, supra note 3 , at 717. 
"criminal" the behavior that runs afoul of them. ${ }^{105}$ Courts and commentators have repeatedly recognized that criminal trials are inherently public, in part because they communicate to the public the force of their collective values. ${ }^{106}$ As Professor Barbara Babcock has noted, criminal trials have cathartic benefits for a society seeking a "reassurance of safety and the satisfaction of revenge." 107 This is a goal fulfilled at all stages of criminal justice-accusation, trial, vindication through acquittal, or condemnation through conviction and punishment. ${ }^{108}$

This ongoing public activity helps to clarify not only the laws that should be enforced, but also the laws that may need modification. ${ }^{109}$ If the affirmative defense discussed in this Article could be described accurately enough to exclude blackmail based on violations of statutes that have fallen into desuetude, it would not necessarily create incentives for blackmailers to invoke statutes that are obsolete. But even the incriminating blackmail discussed in this Article-designed to impose minimal social costs while increasing socially beneficial deterrence-derives much of its legitimacy from

105 See Sally E. Merry \& Susan S. Silbey, What do Plaintiffs Want? Reexamining the Concept of Dispute, 9 Jusr. SYS. J. 151, 153 (1984) (stating that even in the civil context, "by the time a conflict is serious enough to warrant an outsider's intervention ... the grievant wants vindication, protection of his or her rights (as he or she perceives them), an advocate to help in the battle, or a third party who will uncover the 'truth' and declare the other party wrong").

${ }^{106}$ See, e.g., Craig v. Harney, 331 U.S. 367,374 (1947) ("A trial is a public event."); Pennekamp v. Florida, 328 U.S. 331, 361 (1946) (Frankfurter, J., concurring) ("[T]rials must be public and the public have a deep interest in trials."); State v. Schmit, 139 N.W. 2d 800, 807 (Minn. 1966) ("It is not unrealistic even in this day to believe that public inclusion affords citizens a form of legal education and hopefully promotes confidence in the fair administration of justice."); WIGMORE, supra note 9, at 438 ("The educative effect of public attendance is a material advantage. Not only is respect for the law increased and intelligent acquaintance acquired with the methods of government, but a strong confidence in judicial remedies is secured which could never be inspired by a system of secrecy.").

${ }^{107}$ Barbara A. Babcock, Fair Play: Evidence Favorable to an Accused and Effective Assistance of Counsel, 34 STAN. L. REV. 1133, 1140 (1982).

108 See Gerhard O.W. Mueller, Problems Posed by Publicity to Crime and Criminal Proceedings, 110 U. PA. L. REV. 1, 6 (1961) ("The accusation and conviction or acquittal, as much perhaps as the execution of punishment, [help] to restore the imbalance which was created by the offense or public charge, to reaffirm the temporarily lost feeling of security and, perhaps, to satisfy that latent 'urge to punish ...."').

${ }^{109}$ Keeping the enforcement of these statutes in the public sphere not only gives prosecutors some discretion, as Landes and Posner suggest, but would also help to hold the legislative branch accountable for the laws they pass and allow the laws to remain in force. See supra note 48 and accompanying text. 
the fact that the legislature has made prior judgments about the categories of crime subject to blackmail.

Public enforcement of the criminal law also helps to insure that criminals receive the protection of constitutional limitations on law enforcement. ${ }^{110}$ The exclusionary rule creates incentives for law enforcement officers to comply with constitutional mandates because evidence they gain in violation of the Constitution may be inadmissable at the criminal defendant's trial. Blackmailers would not feel these constraints, for criminals might pay blackmail to conceal their crimes even when the blackmailer gains evidence in a manner which would be unconstitutional if the government were the actor. ${ }^{111}$

Even the rhetoric of this Article highlights one of the dangers of departing from public law enforcement. For linguistic ease, this Article has repeatedly referred to the blackmailee as "the criminal." This reveals that in the world of blackmail, the presumption of innocence is only as strong as the blackmailer's uncertainty that she can invoke the affirmative defense. That may not be strong enough to make the private enforcer a suitable proxy for the state.

Indeed, the public enforcement of law may be the necessary condition to balance the individual's interest in procedural protections with the public's interest in the enforcement of substantive norms. ${ }^{112}$ When the United States Supreme Court declared in Richmond Newspapers, Inc. $v$. Virginia ${ }^{113}$ that the Constitution required criminal trials to be open to the public, the Court noted that the "history of open trials in part reflects the widespread acknowledgment . . . that, especially in the administration of criminal justice, the means used to achieve justice must have

${ }^{110}$ See Jeremy Bentham, Rationale of Judicial Evidence 524 (1827) ("Without publicity, all other checks are insufficient: in comparison of publicity, all other checks are of small account. Recordation, appeal, whatever other institution might present themselves in the character of checks, would be found to operate rather as cloaks than checks; as cloaks in reality, as checks only in appearance.").

111 See Robert NOZICK, ANARCHY, StaTe, AND UtOPIA 88 (1974) ("[A]n independent might be prohibited from privately exacting justice because his procedure is known to be too risky and dangerous-that is, it involves a higher risk (than another procedure) of punishing an innocent person or overpunishing a guilty one ...." ).

112 See BABCOCK, supra note 107, at 1140 ("The criminal trial, as the most vivid and visible intersection of state and individual, simultaneously affirms the needs of both our collective and separate selves.").

113448 U.S. 555 (1980). 
the support derived from public acceptance of both the process and its results." 114

Thus, public enforcement is crucial to the declarative function of the criminal law, which involves public education and the vindication of societal norms. These norms are both substantive and procedural, collective and individualist. One product of public education may be deterrence, but the law of blackmail may prove that deterrence does not dominate these other goals.

Judge Posner has asserted that as an empirical matter, blackmail is "quite possibly" a very rare crime. ${ }^{115}$ The number of blackmail cases is inherently difficult to measure, however, because so much of the activity takes place in secret. Even if the crime were very rare, the basis for blackmail's illegality would not be a trivial matter. Blackmail captures the imagination of many legal scholars because more than most crimes, it treads so closely to legitimate, even encouraged, economic activity. In fact, much negotiation takes place under circumstances involving some coercion or pressure on one or both of the parties. We rarely punish this behavior or negate the contracts that emerge from such negotiations. Instead, we struggle with the fine points of negotiation theory and ethics to see how much we can gain within the bounds of legality.

That does not mean that we morally approve of all the advantage-taking that can occur in legitimate negotiation. Some of the residual discomfort associated with incriminating blackmail may stem from this reluctance to expand, rather than contract, the range of permissible pressure in negotiation. But then we come full circle to the problem of distinguishing legitimate from illegitimate threats, proper from improper use of leverage, permissible from impermissible exploitation of superior bargaining strength. Granted, few people commit blackmail. But a rule permitting blackmail could radically change people's business and personal lives, as they anticipate the ways they could become victim and perpetrator of a new species of coercion in negotiation.

114 Id. at $570-71$.

115 See Posner, supra note 3, at 1817. 


\section{CONCLUSION}

This Article has shown that leading blackmail theories have largely ignored the ways in which incriminating blackmail might deter crime by adding to the potential criminal's expected costs and therefore do not satisfactorily explain why incriminating blackmail should be illegal. To highlight this deterrent effect, this Article has considered the consequences of giving blackmailers an affirmative defense if they show that the blackmail "victim" was a criminal. Allowing this affirmative defense and thereby placing the burden on the blackmailer to prove the blackmailee's crime by a preponderance of evidence creates incentives for blackmailers to enhance the costs of criminal activity. By preserving the illegality of other kinds of blackmail-particularly blackmail based on embarrassing but not incriminating information-this affirmative defense avoids creating incentives to blackmail when the blackmail would not deter crime.

The reluctance to decriminalize even this limited form of blackmail signals a more general desire for public involvement in articulating and enforcing social norms. Even rules that increase deterrence may harm the public if they fundamentally alter the nature of law enforcement in ways inconsistent with prevailing notions of justice. The fear is not that blackmail precludes public justice or reduces the quantity of public involvement. Rather, the concern is that we fundamentally alter the quality of justice when we take enforcement away from a public audience. Blackmail based on incriminating information is essentially private justice. It allows private parties to assess the reach of the criminal law. It involves no public review of the facts or interpretation of the law. It transfers an otherwise public process to a private venue where records are sealed and results are inaccessible.

Debate is ongoing about the dangers and benefits of private justice in the civil context. As methods of private dispute resolution evolve and parties increasingly turn from public fora to private processes, we will discover the extent to which private processes are consistent with and affect precedent, satisfy participants, and produce results that the parties and the public can live with. At this point, little evidence exists to allow us to assert conclusively that private justice resolves civil conflicts justly. If we maintain some skepticism in the civil context, how much more cautious ought we to be in the criminal context, where the rights at stake are graver and the unresolved conflicts presumably more destructive? Blackmail may perform some of the functions of criminal justice admirably as it deters crime. But blackmail as private justice cannot substitute for criminal justice, which by its very nature requires public processes. 